\title{
Categoria etnică din perspectivă lingvistică
}

\author{
Răzvan Săftoiu ${ }^{\circledR *}$ \\ Facultatea de Litere, Universitatea „Transilvania” din Brașov, Bd. Eroilor 29, 500036 Braşov, România
}

\section{Despre articol}

Istoric:

Primit 25 ianuarie 2017

Acceptat 27 ianuarie 2017

Publicat 23 martie 2017

Cuvinte-cheie:

sociolingvistică

antropologie lingvistică

diacronie

\begin{abstract}
Rezumat
În această lucrare, propun analiza din perspectivă lingvistică a construcției unei categorii etnice din România care este denumită prin cel puțin doi termeni: țigan și rom. Conceptul de categorie se referă la membrii unui anumit grup care se diferențiază de alte grupuri printr-un set de elemente specifice recunoscute la nivelul unei comunități mai largi. In interacțiune, indivizii apelează frecvent la categorii și la setul de trăsături pe care îl poartă o anumită categorie, deoarece este mai ușor de operat cu seturi de cunoștințe decît cu referințe pentru fiecare individ în parte. Analiza are la bază o serie de expresii și locuțiuni, proverbe şi glume care au circulat (sau încă mai circulă) în spațiul românesc și care au conturat, la nivelul mentalității colective, imaginea unei categorii etnice a cărei denumire (încă) oscilează între doi termeni. Textele au fost grupate în funcție de diverse stereotipuri asociate categoriei etnice avute în vedere, evidențiind conotațiile peiorative ale utilizărilor termenului țigan în raport cu categoria etnică rom, o categorie „goală” de semnificație, care poate fi „umplută” cu elemente ce pot creiona o imagine pozitivă.
\end{abstract}

\section{Introducere}

De-a lungul timpului, cercetători din cele mai diverse domenii-filozofie, antropologie, educație, sociologie, științe ale limbajului, științe politice, studii literare și culturale—au fost procupați de înțelegerea și definirea conceptului de identitate. Acesta poate avea un sens acceptat din punct de vedere birocratic, însă prin acțiuni dialogice vorbitorii accesează și se folosesc de mai multe identități. În numeroase schițe, I.L. Caragiale a fost preocupat să surprindă particularităţile comunicării de zi cu zi şi a ilustrat modul în care persoane cunoscute sau necunoscute se angajează activ într-o conversație „după cîteva momente de tăcere”. Fie că sînt în tren (Accelerat no. 17, Identitate, Búbico), în vizită (Vizită...) sau „la dejun pe iarbă” (Gazometru), personajele sînt interesate să stabilească o relație socială, adoptînd o identitate socială. Oferim spre exemplificare un extras din schița Accelerat no. 17, publicată în 1899:

„Domnul intră în cupeu după negustor, care s-a dezbrăcat de șubă și șade cu sacul pe mînă.

- Bonsoar, zice domnul.

- Bonsoar, răspunde negustorul.

Și domnul se așază pe fotoliul din față, după ce și-a pus geamantanul în plasă și tartanul la căpătîi.

Doi-trei kilometri tăcere.

- Mergeți departe? întreabă domnul.

- De! Departe și nu departe... Pînă la Mărășești...

- Pînă la Mărășești?

- Da. Dar dv.?

- Și eu tot pînă la Mărășești.”

(Caragiale, 1985, p. 152)

*Adresă de corespondență: razvan.saftoiu@unitbv.ro. 
Contextul ales de scriitor, călătoria cu trenul, este unul care favorizează angajarea într-o conversație „convențională”. În fragmentul ales, remarcăm indicația „scenică” referitoare la păstrarea tăcerii și modalitatea de inițiere a conversației: o întrebare parțial deschisă, prin care vorbitorul rupe tăcerea și își manifestă interesul față de persoana care călătorește în același compartiment. Caragiale reușește astfel să pună în valoare un aspect important al comunicării de zi cu zi, relaționarea fatică. Conceptul pe care îl folosim a fost introdus și definit după aproape două decenii, în 1923, de antropologul britanic Bronislaw Malinowski.

Caragiale și Malinowski vin din două direcții diferite, însă observațiile lor conduc spre aceeași concluzie: atunci cînd un individ se află în prezența altuia și între ei nu există o stare conflictuală anterioară, cei doi au tendința de a interacționa verbal. Schițele lui Caragiale au la bază observarea atentă a comportamentului verbal și non-verbal al românilor de la sfîrșitul secolului al XIX-lea, iar observațiile lui Malinowski se bazează pe investigații ale unor triburi din Oceania, pe care antropologul le-a studiat la începutul secolului al XX-lea. În urma analizelor detaliate, Malinowski formulează o concluzie cu caracter universal: „ne aflăm în fața unui nou mod de a folosi limbajul, comuniunea fatică” (Malinowski, 1923, p. 314-316).

În această lucrare, mă voi opri asupra unui tip particular de identitate, cea etnică, pe care o voi aborda din perspectivă sociolingvistică și dialogică. Astfel, identitatea va fi înțeleasă drept un set de trăsături distinctive ale unui membru al unei anumite comunități, caracteristici care se evidențiază fie prin locuțiuni şi asocieri lexicale şi culturale, fie prin jocuri dialogice cu membri ai aceleiaşi comunităţi sau ai alteia, într-un anumit context.

\section{Teorii despre identitate}

Identitatea este, în primul rînd, un concept social (Gumperz, 1982), deoarece oamenii sînt ființe sociale care își caută identitatea personală prin raportare la alți indivizi, într-o anumită comunitate. Teoria identității sociale s-a dezvoltat în anii '60 și are la bază două tipuri diferite de procese-procese de grup și procese interpersonale-care pot explica apariția și dezvoltarea unor asocieri lexicale. La nivel teoretic, se face distincția între identitate socială și identitate personală. Astfel, identitatea socială este „concepția individului despre propriul eu în termeni de trăsături caracteristice ale categoriei sociale de apartenență” (Boncu, 2004), iar identitatea personală este „concepția individului despre propriul eu ca unic și distinct de ceilalți indivizi” (Boncu, 2004). Cele două identități constituie, de fapt, elemente ale unui continuum, indivizii încercînd să-și găsească și să-şi adapteze identitatea personală în funcție de cerințele societăţii. Altfel spus, pentru a se conforma, individul va alege un comportament de grup, caracterizat de etnocentrism, favorizarea in-group-ului, discriminare, stereotipizare (Boncu, 2004). La nivel lingvistic, conformarea se traduce prin identitatea lingvistică pe care o considerăm o componentă a identităţii sociale (Guggenberger \& Holzinger, 1993), deoarece alegerile lingvistice reflectă poziția adoptată de vorbitor într-un anumit context social pentru a marca apartenența la un anumit grup.

În alte studii, identitatea este discutată ca proces (Hall, 2000), nu ca atribut al indivizilor, deoarece identitățile se construiesc în timpul dialogului și prin adaptarea permanentă la acțiunile verbale anterioare. Altfel spus, indivizii nu intră în interacțiune cu un set predefinit de identități, ci şi le adaptează în funcție de scopurile dialogice (Weigand, 2015), în funcție de stadiul și direcția conversației. Identităţile sînt performate și negociate în timpul interacțiunii, iar alegerile lingvistice devin semnale ale tipului de identitate emergent. Considerăm că identitatea nu este un concept static, deținut de cineva la un moment dat, ci unul dinamic, ce se construiește prin schimburi verbale.

Joseph (2004) propune o reevaluare a funcțiilor limbajului, deoarece-dincolo de funcția de comunicare (înțeleasă ca intenție de transmitere către un receptor) și cea de reprezentare (înțeleasă ca evocare mentală a lumii înconjurătoare) -indivizii folosesc limbajul pentru a se raporta la alți indivizi. Așadar, în primul rînd, ar trebui să mergem dincolo de înțelegerea formală a limbajului (sensuri ale cuvintelor și reguli sintactice) și să ne oprim asupra identificării contextului în care cineva spune ceva despre cineva/ ceva, deoarece vorbitorul are un anumit scop - fie fatic, fie tranzacțional. În al doilea rînd, limbajul folosit creionează o imagine a vorbitorului în mintea ascultătorului, producîndu-se astfel categorizarea. 
Fiecare individ dorește să-şi construiască o anumită identitate. Există însă identități multiple - unele dorite, altele nedorite. Vorbitorul se vede pus în fața unei dileme pentru a alege identitatea cea mai potrivită pentru o anumită situație, iar „navigarea” printre diferitele identități se face prin discurs. Astfel, afirmaţiile, întrebările sînt mișcări discursive pe care un individ le folosește pentru a-și construi o anumită identitate: cea de „director deferent”, de „președinte îngrijorat”, de „jurist priceput” etc. Din perspectiva teoriei identității, schimbul de formule de salut, spre exemplu, nu este pur și simplu ritualic, dictat de comuniunea fatică, ci este o mișcare interacțională relevantă atît pentru statutul participanților, cît și pentru caracterizarea relației în acel moment. Astfel, persoana care salută prima se prezintă ca un individ care dorește să aibă o relație bună cu interlocutorul său, iar cel care răspunde la salut recunoaște identitatea adoptată de celălalt și acționează în consecință. În cazul în care interlocutorul nu răspunde la salut, el și-a asumat o identitate nedorită, prin care susține neimplicarea în relația socială iniţiată de partenerul său de interacțiune. Secvențele fatice inițiale pot fi analizate din punctul de vedere al unui ,joc” al identităților, însă este un joc atît la nivel mental, cît și la nivel discursiv.

Goffman (1959) a adus din filosofia chineză conceptele de Yin (loc întunecos, introvertit) și Yang (loc însorit, extravertit), și le-a transpus în interacțiunea cotidiană sub forma unor jocuri în care actorii (indivizii) performează pe scena relațiilor interumane atît în regiuni „expuse”, cît și în regiuni „ascunse” publicului. Fiecare individ joacă un anumit rol și își expune mai multe măști, în funcție de persoana cu care interacționează și contextul în care se produce interacțiunea, ținînd în permanență seama de masca celuilalt, astfel încît atît propria imagine, cît și imaginea celuilalt să nu aibă de suferit. "Jocul măştilor” este de fapt jocul identităților pe care indivizii le construiesc și le reconstruiesc permanent în funcție de context, de cultură, de identitatea interlocutorului. Așadar, în această lucrare identitatea este considerată un proces dinamic prin care indivizii își manifestă apartenenţa la un grup social, într-un anumit context.

În contextul dezvoltării abordărilor etnometodologice, Sacks (1972) a propus conceptul de „categorie de apartenență” (engl. membership category). Deși conceptul a fost utilizat cu precădere în studiile de analiză a conversației, îl voi folosi în această lucrare deoarece raportarea la realitate prin categorii este o modalitate de construire a identității. Categoria presupune existența unor drepturi și obligații ale indivizilor, care se actualizează diferit, în funcție de contextul interacțional. Cercetările lui Sacks au avut la bază înregistrări efectuate la Centrul de prevenire a suicidului din Los Angeles care i-au permis ulterior efectuarea de analize detaliate pentru formularea unor concluzii privitoare la utilizarea categoriilor în interacțiune.

Categoriile sînt clasificări sau tipuri sociale pe care vorbitorii le folosesc pentru a identifica și descrie persoane (Schegloff, 2007). Indivizii apelează frecvent la categorii și la setul de trăsături pe care îl poartă o anumită categorie, deoarece este mai ușor de operat cu seturi de cunoștințe decît cu referințe pentru fiecare individ în parte. Apartenența la o anumită categorie se face pe baza tipului de relație și a tipului de cunoștințe. Dacă persoanele care interacționează sînt cunoscute, se vorbește despre o relație adecvată (engl. proper relationship, Rp), însă dacă persoanele sînt necunoscute, se vorbește despre o relație inadecvată (engl. improper relationship, Ri). În mod similar, se face distincția între cunoștințe adecvate (engl. proper knowledge, $\mathrm{Kp}$ ), asociate profesioniștilor dintr-un anumit domeniu, și cunoștințe inadecvate (engl. improper knowledge, Ki), asociate neprofesioniștilor. Raportul dintre tipul de relație și tipul de cunoștințe se poate schimba dacă avem în vedere faptul că indivizii stabilesc relații inadecvate, adresîndu-se unor persoane necunoscute (medici, spre exemplu) dar care dețin cunoștințe adecvate într-un anumit domeniu, pentru a-și satisface scopul interacțional (obținerea unui diagnostic și al medicamentaţiei, spre exemplu). Altfel spus, îi încadrăm pe alți indivizi din jurul nostru într-o anumită categorie, cea a deținătorilor de cunoștințe adecvate, pentru a satisface propriul scop comunicativ. Încadrarea se face pe baza unui set de activități, motive, drepturi, obligații şi competențe, ceea ce permite o identificare și raportare mai ușoară în comunicarea interpersonală. Raportarea la categorii este de cele mai multe ori inconștientă, structura categoriilor existînd la nivelul mentalului colectiv și reflectîndu-se în locuțiuni și asocieri lexicale și culturale (Zafiu, 2009).

Analiza pe baza categoriilor de apartenență are la bază modul în care indivizii organizează informația 
despre alții, vizează modul în care vorbitorii utilizează diverse categorii (familie, religie, minoritate etc.) prin raportare la membri specifici (mamă, tată, ortodox, catolic, român, american etc.), pe baza unui set comun de atribute și comportamente (Sacks, 1972; Stokoe, 2012). Apartenența la o anumită categorie este determinată de particularități lingvistice, culturale sau situaționale ce fac posibilă observarea și identificarea unor categorii (Maynard \& Zimmerman, 1984; Eglin, 2002). La nivelul comunicării interpersonale, raportarea se poate face la două categorii diferite, interactanții fiind conștienți de specificul celeilalte categorii (vorbim „noi” despre „ei”), sau la membrii aceleiași categorii (vorbim „noi” despre „noi”). În cea de-a doua situație, putem vorbi chiar despre umor autodepreciativ, mai ales dacă sînt evidențiate aspecte despre care „ceilalți” rîd. Un caz aparte este acela în care sînt aduse în prim-plan trăsături negative ale unei categorii fără a conștientiza că interlocutorul sau un alt participant la interacțiune este un membru al respectivei categorii. Interacțiunea poate avea efecte negative asupra relației interpersonale, deoarece sînt abordate subiecte tabu pe baza trăsăturilor negative ale categoriei din care face parte interlocutorul, analiza putînd fi făcută inclusiv la nivelul strategiilor impoliteții negative (Culpeper, 2008).

Uneori, utilizarea unei anumite descrieri a unei activități poate activa o anumită categorie. Spre exemplu, Sacks (1986) a analizat relația dintre membrii unei categorii în enunțul „Mama a ridicat copilul”, evidențiind faptul că înțelegerea corectă a acestui enunț este că mama și-a ridicat propriul copil. Interpretarea are la bază apartenența celor doi membri (mama și copilul) la aceeași categorie (familie), precum și existența unor drepturi și obligații ale acestora. Astfel de categorii pot fi identificate în interacțiune, însă în acest articol mă voi referi mai degrabă la invocarea deliberată a unei anumite categorii. Consider că această utilizare este strategică, deoarece îi permite vorbitorului să sublinieze rolul pe care îl are în interacțiune, să se distanțeze sau să se apropie de interlocutor.

\section{Corpus și metodologie}

Unul dintre scopurile clasificării în funcție de tipuri sociale este acela de a descrie persoane. Descrierile se pot referi la femeia, bărbatul, copilul, prietenul, bunica, politicianul etc. În momentul în care un individ este identificat drept membru al unei anumite categorii, la nivel mental se face legătura cu drepturile și responsabilitățile respectivei categorii și cu tipul de comportament considerat adecvat categoriei. Mecanismul prin care o categorie își constituie setul de atribute poate fi rezumat astfel: caracteristicile personale ale unui membru sînt atribuite categoriei din care face parte, iar ulterior, caracteristicile se răsfrîng asupra tuturor membrilor acelei categorii. Prototipul unei categorii se formează numai din acele caracteristici individuale care sînt observate în mod repetat la mai mulți indivizi din aceeași categorie. Această situație caracterizează categoriile etnice, deoarece membrii sînt deja identificați. Alteori, punctul de pornire poate fi o anumită activitate, un anumit comportament sau atitudine. În acest caz, indivizii care dezvoltă respectivul comportament vor fi încadrați într-o altă categorie. Observăm că un individ poate face parte din mai multe categorii în funcție de caracteristicile care îi sînt atribuite înainte sau în timpul interacțiunii.

Raportarea la categorii este de cele mai multe ori inconștientă, structura categoriilor existînd la nivelul mentalului colectiv și fiind reflectată în modul în care vorbitorii își structurează discursul. Spre exemplu, dacă relația dintre interlocutori este doctor-pacient, răspunsul la întrebarea „Cum vă mai simțiți astăzi ?” va fi formulat din prisma categoriilor implicate în dialog. Astfel, în formularea răspunsului, pacientul se va raporta la starea medicală și la întîlnirile anterioare cu medicul. Alteori, raportarea la categorii poate fi explicită și strategică. Spre exemplu, replica „Ești mama noastră!” spusă de un copil mamei sale care nu a făcut distincția între gemeni este interpretată ca un reproș, mama fiind „amendată” deoarece nu s-a încadrat responsabilităților impuse de categoria mamă, printre care se numără capacitatea de a distinge între propriii copii. Observăm că, atunci cînd un individ nu corespunde uneia sau mai multor atribute asociate categoriei în care a fost încadrat, apare o ruptură la nivel mental care se manifestă la nivel discursiv prin atenționare, încercîndu-se o reașezare în urma unei deviaţii prin verbalizarea categoriei și prin actualizarea responsabilităților asociate. În mod asemănător, presupunem că, în timpul unui dialog, un vorbitor folosește replica „Nu fi țigan!”. În acest caz, sînt actualizate atribute specifice categoriei țigan cu 
scopul de a atrage atenția celuilalt de a nu recurge la un comportament specific unei categorii din care nu face parte.

Secțiunea următoare este dedicată analizei unor expresii și locuțiuni, proverbe și glume care au circulat (sau încă mai circulă) în spațiul românesc și care au conturat, la nivelul mentalității colective, imaginea unei categorii etnice a cărei denumire (încă) oscilează între doi termeni. Materialul lingvistic a fost grupat în funcție de diverse stereotipuri asociate categoriei etnice avute în vedere, evidențiind conotaţiile peiorative ale utilizărilor termenului țigan în raport cu categoria etnică rom. În această lucrare, termenul țigan nu este folosit cu nici o conotație negativă și nici în sens discriminatoriu. Perspectiva pe care o voi adopta este una interdisciplinară: pe de o parte sociolingvistică, deoarece privește modul în care se construiește un anumit tip de identitate prin discurs, pe de altă parte critic-discursivă, deoarece mă voi opri asupra implicațiilor utilizării categoriilor etnice țigan și rom la nivelul comunicării interpersonale. Așadar, întrebările prezentei cercetări sînt:

1. În ce măsură atributele unei categorii se pot modifica, în sensul adăugării unor noi caracteristici sau al modificării caracteristicilor existente?

2. Care sînt implicațiile utilizării categoriilor etnice la nivelul comunicării interpersonale?

În analiza datelor, voi folosi de asemenea proprietățile categoriilor identificate de Sacks (1992) - apartenență (engl. membership), inferență (engl. inference rich) și reprezentativitate (engl. representative). Prima proprietate presupune existența unei înțelegeri tacite la nivelul societății, potrivit căreia categoriile sînt complete și cuprind întreaga populație, astfel încît fiecare individ aparține cel puțin unei categorii, fiind imposibil ca un individ să nu facă parte din nici o categorie, deoarece însăși apartenența la o societate este dependentă de apartenența la o categorie. Cea de-a doua proprietate se referă la cunoștințele pe care le putem obține despre un individ odată ce a fost încadrat într-o categorie, fiindu-ne uşor să găsim un subiect de conversație fie pe baza cunoștințeor stocate la nivelul mentalului colectiv, fie pe baza cunoștințelor împărtășite din interacțiuni anterioare. Cea de-a treia proprietate se referă la faptul că fiecare membru al unei categorii este prezumtiv reprezentantul întregii categorii, astfel încît individul se pliază pe șablonul de la nivelul mentalului colectiv.

\section{Analiza datelor}

Studiile de istorie genetică au atestat faptul că populația romă a migrat din nord-estul Indiei cu peste 1500 de ani în urmă. Caracterul nomad al populației și lipsa unei limbi unitare au determinat apariția a numeroase mituri și legende care s-au perpetuat și au condus la dezvoltarea, la nivel lingvistic, a unor expresii și locuțiuni bazate pe stereotipuri, șabloane construite de populația majoritară („noi”) pentru a se raporta la populația minoritară („ei”). În cele ce urmează, pentru o mai bună evidențiere a formării atributelor categoriei țigan, am grupat principalele expresii și locuțiuni care conțin etnonimul țigan în funcție de stereotipul promovat.

\subsection{Stereotipul țiganii fură}

La nivel lingvistic, textele care au la bază acest stereotip sînt numeroase, comportamentul inadecvat (furtul) fiind atribuit întregii categorii: Cîți țigani atîția hoți. Prin invocarea și alăturarea a două categorii distincte (categoria etnică - țigan și categoria ocupațională - hoț) se produce transferul de semnificație dintr-o categorie în alta. Același mecanism funcționează în alte proverbe: Țiganul pînă nu fură nu se ține om, E uşor să înveți să furi între țigani, Iși taie pîinea cu cuțitul țiganului. Fiecare dintre aceste proverbe se bazează pe asocieri negative ale instabilității teritoriale-deoarece populația de etnie romă este cunoscută drept populație nomadă, care locuia de obicei la marginea orașelor, în locuințe improvizate一, și ale necunoscutului-părăsirea zonei de confort și siguranță produce anxietate manifestată prin povești cu personaje negative, care pot face rău. Uneori, practicile învechite ale populaţiei au fost lexicalizate, proverbul Țiganul urcă și pe calul altuia făcînd trimitere la furtul de cai pentru ca populația nomadă să-și asigure transferul dintr-o parte în alta. Etnonimul grupului etnic a condus și la formarea unor derivate 
precum verbul a țigăni, dar și a se țigăni, sensurile fiind diferite. Primul verb apare în contexte de tipul m-a țigănit („am fost furat, păcălit”), iar cel de-al doilea verb apare în contexte legate de negociere zgomotoasă, ceartă neproductivă sau insistență sîcîitoare. Uneori, verbul este completat de structura ca la ușa cortului, practica observată la această categorie etnică fiind invocată prin raportare spațială.

Această activitate este surprinsă și în sintagma ciștig țigănesc, presupoziția fiind că veniturile populației de etnie romă se bazează pe furt. Mai mult, proverbul E uşor să înveți să furi între țigani se bazează pe asocierea dintre practica recurentă și experiența acumulată în timp. Dincolo de nivelul lexical, activitatea predilectă este exploatată ca sursă tematică în glumele etnice. Spre exemplu, 35\% din glumele etnice cu ţigani de pe un site web (www.bancuri.net) sînt construite în jurul acestei teme. Davies (1990) a analizat glumele etnice pornind de la teoria propusă de Raskin (1985) care are la bază opoziții binare ale scenariilor (Semantic Script Theory of Humour - SSTH). Cele două scenarii se referă la prostie (engl. stupidity) și la istețime (engl. canniness). Pentru a analiza modul în care o anumită activitate asociată categoriei țigan este exploatat în glumele etnice, am ales două exemple.

(1) Doi țigani revin acasă cu un sac plin de bancnote după ce au jefuit o bancă.

- Luca, hai să numărăm banii!

- Las-o baltă, Flăcărică, oricum aflăm suma de la știri...

(2) Țiganul aduna vreascuri pe braț. La un moment dat, apare pădurarul și îl întreabă:

- Ce faci, mă, iar ai venit la furat de lemne?

- $\mathrm{Nu}$, domnule, le adun pentru iepuri.

- Ce, mă, iepurii tăi mănîncă lemne?

- Eh, dacă nu le mănîncă, le bag pe foc.

Dacă în exemplul (1), scenariul prostiei este evident în replica lui Luca (Las-o baltă, Flăcărică, oricum aflăm suma de la știri), avînd la bază un alt atribut al categoriei etnice-lipsa de implicare, delăsarea, neparticiparea și inactivitatea-, în exemplul (2), scenariul este unul ambiguu. Pe de o parte, se poate identifica scenariul prostiei, deoarece țiganul, reprezentant al categoriei marginale, a fost prins la furat (Ce faci, mă, iar ai venit la furat de lemne?) de către pădurar, reprezentant al categoriei centrale; pe de altă parte, se poate identifica scenariul istețimii, deoarece țiganul propune o soluție „salvatoare” (Eh, dacă nu le mănîncă, le bag pe foc), ceea ce evidențiază un alt atribut al categoriei: ingeniozitatea. De altfel, autocaracterizarea pozitivă a fost observată și în alte studii sociologice (Lazăr, 2009, p. 27-28) și vine să contrabalanseze proiecția negativă a grupului majoritar asupra grupului minoritar.

\subsection{Stereotipul țiganii sint violenți}

Rolul de hoț este atribuit populației de etnie romă și cu rol pedagogic, populația majoritară folosind grupurile minoritare pentru a performa indirect diverse acte de vorbire: atenționare sau amenințare (Te fură țiganii). Expresii precum Te dau la țigani, Chem țiganii să te ia dacă nu ești cuminte, Nu ieși din curte că te bat țiganii, E obişnuit precum calul țiganului cu bătaia evidențiază un alt stereotip asociat categoriei etnice: violența, care se poate manifesta fizic sau verbal (Se ceartă ca la uşa cortului).

\subsection{Stereotipul țiganii cerșesc}

Insistența, de cele mai multe ori sîcîitoare, precum și lipsa de respect față de ceilalți membri ai societății conturează un alt stereotip asociat categoriei etnice țigan: cerșetoria ca mijloc de existență. Modalitatea de a cere este insistentă și deranjantă pînă la exasperare și este surprinsă în proverbe și expresii precum Dă-i țiganului azi și vine și mîine, T,iganul e ca rîia, Cere ca țiganul. Lipsa unui loc de muncă este corelată cu lipsa de implicare în viața comunității şi mutarea în alt loc, fapt ce este surprins de un alt atribut al categoriei: nomadismul. Deși migrația nu este în esență un aspect negativ, ea este asociată cu migrațiile invazive din secolele III-VIII și devine atribut al persoanelor nestatornice. Așa cum am comentat mai sus, schimbarea provoacă anxietate în mentalul colectiv și trebuie găsite modalități de a combate această stare prin raportare la „celălalt”, care vine din altă parte. De altfel, raportarea la „celălalt” este esențială 
pentru construirea identității sociale. Prin acest proces, reprezentanții majorității se autocaracterizează și îi caracterizează pe reprezentanții minorității.

\subsection{Stereotipul țiganii au o condiție socială joasă}

Nomadismul, înțeles ca mod de viață primitiv, conduce la un alt stereotip destul de activ la nivelul mentalității colective: țiganii au o condiție socială joasă, fiind chiar asociați cu o oarecare întîrziere din punctul de vedere al civilizației. „Primitivismul” este evidențiat, la nivel lexical, de numeroasele expresii care trimit la nevoile primare ale omului, precum hrana și igiena, care nu sînt satisfăcute: Dacă ar face muștele miere, ar mînca și țiganii cu lingura, Cînd îi e foame, țiganul cîntă și dansează. Societatea, prin membrii ei, atribuie statusuri indivizilor în funcție de locul pe care îl ocupă un anumit individ în ansamblu. Prin interacțiune socială și verbală, se ajunge la formarea unor grupuri de insideri, cei care împărtășesc acelaşi status social, și outsideri, cei care rămîn în afara grupului din diverse motive, conformarea la regulile sociale fiind unul dintre ele. Deoarece nu au un loc stabil și nu își pot asigura nevoile curente, țiganii sînt lăsați în afara grupului și sînt stigmatizați.

\subsection{Stereotipul țiganii nu își pot depăşi condiția socială}

Stigmatul este susținut de un ultim stereotip pe care l-am identificat în corpusul avut în vedere: țiganii nu ișsi pot depăşsi condiția socială. Condiția socială este una asumată și imposibil de depășit, idee susținută de expresiile Țiganul e țigan și-n ziua de Paști, Nici răchita pom de bute, nici țiganul om de frunte, Nici salcia nu-i ca pomul, nici țiganul nu-i ca omul, Te îneci ca țiganul la mal. Așa cum unii copaci nu pot fi folosiți pentru confecționarea de obiecte casnice, deoarece nu au consistența necesară, tot așa nici țiganii nu au atributele specifice altor categorii.

\subsection{O nouă categorie: rom}

În secțiunile anterioare, am identificat principalele atribute ale categoriei ţigan, atribute ce au fost stabilite pe baza unor stereotipuri. Așa cum am comentat, populația majoritară a atribuit, în timp, trăsături negative categoriei țigan pe baza unor practici neacceptate la nivel social (furtul) și al incapacităţii observate de a-și asigura nevoile primare de supraviețuire (hrană și igienă), în contextul nomadismului. Raportarea la „celălalt” nu poate rămîne fără răspuns din partea categoriei vizate, astfel încît a fost propusă o nouă categorie: rom. Din păcate însă, categoria rom nu este reprezentată la nivel lingvistic în expresii, locuțiuni și nici în glume etnice, ceea ce conduce la ideea că, deocamdată, este o categorie „goală”, fără atribute, în curs de constituire. Astfel, au apărut denumiri de discipline (Gramatica limbii romani, Limba şi literatura romani, Cultură și civilizație romani, Locuri speciale pentru studenții romi) sau au fost înființate instituții dedicate grupului minoritar studiat (Centrul de incluziune socială pentru cetățenii de etnie romă).

\section{Implicații ale utilizării categoriilor etnice}

În urma analizei din Secțiunea 4, am observat că atît stereotipurile, cît și glumele etnice sînt atribuite populației majoritare (centrale) care se raportează la populația minoritară (marginală/ periferică). Astfel, performerii glumelor aparțin întotdeauna populației centrale, iar glumele au drept țintă reprezentanţi ai populaţiei marginale (niciodată invers, cf. Davies, 1990; Laineste, 2005). Pentru a putea performa glume a căror țintă este o minoritate etnică, reprezentanții populației minoritare se aseamănă cu populația majoritară în sensul că vorbesc aceeași limbă (uneori particularitățile fonetice și/ sau lexicale sînt ținta glumelor) și împărtășesc același spațiu cultural.

Marin (2010) a studiat construcția identităţii etnice a țiganilor dintr-o comunitate din Braşov și consideră că există o „criză identitară” la ambele poluri: atît populația majoritară, cît și cea minoritară caută să-şi construiască o imagine pozitivă. Ideea este susținută și de Lazăr (2009, p. 27) care a observat că „romii oferă despre ei înșişi o imagine care contrastează puternic cu ceea ce spun reprezentanții celorlalte grupuri etnice despre romi: aceștia au preponderent calități, fiind descriși prin epitetele: „primitori”, „cumsecade”, „harnici”, „uniți””. 
Principala idee care se desprinde din studiile în care au fost analizate cele două categorii „concurente” este că fiecare categorie are atribute proprii de care vorbitorii sînt conștienți și le aleg în funcție de scopurile comunicative. În timp, categoria țigan a „atras” atribute negative, însă cuvîntul nu poate fi eliminat din limba română. Deocamdată, categoria rom este la nivelul constituirii, vorbitorii înșişi fiind conștienți de acest lucru: „Cînd aud rom, mă gîndesc la țiganii care sînt civilizați, muncesc și nu fură... dar cînd aud țigani, deja mă gîndesc la închisoare, alcool și altele” (Sorin, 16 ani, din satul Gîrcini, jud. Brașov) (Marin, 2010, p. 10). Coexistența a doi termeni și implicit a două categorii nu este imposibilă din moment ce „existența unui termen oficial nu exclude păstrarea în uzul curent a altor cuvinte” (Zafiu, 2009).

\section{Concluzii}

În această lucrare am pornit de la ideea că identitatea este un proces dinamic prin care indivizii își manifestă apartenența la un grup social, într-un anumit context spațial și temporal. Identitatea este negociată în timpul interacțiunii, prin schimburile verbale, indivizii „navigînd” printre identităţi diverse. De asemenea, am definit noțiunea de categorie de apartenență prin raportare la studiile de analiza conversației. Indivizii recurg la categorii pentru a se raporta mai ușor la realitatea extralingvistică prin seturi de atribute. La acest nivel, m-a interesat să observ în ce măsură atributele asociate cu o anumită categorie, țigan, sînt stabile sau se pot modifica în timp. Pe baza analizei, concluziile conduc la ideea că, în general, categoria etnică este parțial flexibilă, deoarece noi atribute pot fi adăugate numai în sensul celor existente. Astfel, categoria țigan nu poate primi atribute pozitive, ea fiind constituită la nivelul mentalului colectiv din stereotipuri negative. În schimb, pentru categoria rom nu am identificat reprezentări la nivel lingvistic în expresii, locuțiuni și nici în glume etnice, concluzia fiind că, deocamdată, rom desemnează un grup etnic. De asemenea, analiza conduce și la o altă concluzie: categoriile se dezvoltă în timp.

În privința implicaţiilor utilizării categoriei țigan în comunicarea interpersonală, am putut observa că utilizarea acesteia poate fi interpretată drept o formă de agresivitate verbală prin prisma stereotipurilor negative conținute, constituindu-se în același timp într-o sursă pentru glume etnice, alături de categorii „internaţionale” precum albanezi, evrei, unguri, dar și „naționale” - ardeleni, moldoveni, olteni. De altfel, investigarea modului în care sînt utilizate și reciclate categoriile etnice în glume, dar și în discursul politic este o temă de cercetare ce merită continuată pentru a formula concluzii pertinente privitoare la dezvoltarea, în timp, a categoriilor de apartenență.

\section{Bibliografie}

Boncu, Ș. (2004). Psihologie socială. Curs, [online].

Caragiale, I.L. (1985). Momente și schițe, Editura Eminescu, București.

Culpeper, J. (2008). Reflections on impoliteness, relational work and power, în Bousfield, D. \& Locher, M. (eds), Impoliteness in Language, Mouton de Gruyter, Berlin, p. 17-44.

Davies, C. (1990). Ethnic Humour around the World, Indiana University Press, Bloomington.

Eglin, P. (2002). Members' gendering work: Women, feminists and membership categorization analysis, în „Discourse \& Society”, vol. 13, p. 819-825, Crossref.

Goffman, E. (1959). The Presentation of Self in Everyday Life, Anchor Books, New York.

Guggenberger, H. \& Holzinger, W. (eds) (1993). Neues Europa - Alte Nationalismen: Kollektive Identitäten im Spannungsfeld von Integration und Ausschliessung, Drava, Klagenfurt.

Gumperz, J. (ed.) (1982). Language and Social Identity, Cambridge University Press, Cambridge, Crossref.

Hall, S. (2000). Who needs identity? în du Gay, P., Evans, J. \& Redman, P. (eds), Identity: A Reader, Sage and the Open University, London, p. 15-30.

Joseph, J. (2004). Language and identity. National, ethnic, religious, Palgrave Macmillan, Hampshire.

Laineste, L. (2005). Targets of Estonian ethnic jokes within the theory of ethnic humour (Ch. Davies), în „Folklore: Electronic Journal of Folklore", p. 7-24, Crossref.

Lazăr, M. (2009). Semantică socială și etnicitate. O tipologie a modurilor identitare discursive în România, în "Studii de atelier. Cercetarea minorităților naționale din România”, nr. 26, Cluj-Napoca.

Malinowski, B. (1923). The problem of meaning in primitive languages. A study of the influence of language upon thought and of the science of symbolism, în Ogden, C. K. \& Richards, I. A. (eds), The Meaning of Meaning, Harcourt, London, p. 296-336. 
Marin, T. (2010). „We are Gypsies, not Roma!” Ethnic identity constructions and ethnic stereotypes - an example from a gypsy community in central Romania, în „Studii de atelier. Cercetarea minorităților naționale din România”, nr. 36, Cluj-Napoca.

Maynard, D. \& Zimmerman, D. (1984). Topical talk, ritual and the social organization of relationships, în "Social Psychology Quarterly", 47, p. 301-316, Crossref.

Raskin, V. (1985). Semantic Mechanisms of Humor, de Gruyter, Berlin, Crossref.

Sacks, H. (1972). On the analyzability of stories by children, în Gumperz, J.J. \& Hymes, D. (eds), Directions in sociolinguistics: The ethnography of communication, Rinehart \& Winston, New York, p. 325-345.

Sacks, H. (1986). Some consideration of a story told in ordinary conversations, în „Poetics”, vol. 15, nr. 1-2, p. 127-138, Crossref. Sacks, H. (1992). Lectures on conversation, 2 vol., Basil Blackwell, Oxford.

Schegloff, E. (2007). Categories in action: person-reference and membership categorization, în „Discourse Studies”, vol. 9, nr. 4, p. 433-461, Crossref.

Stokoe, E. (2012). Moving forward with membership categorization analysis: Methods for systematic analysis, în „Discourse Studies", vol. 14, nr. 3, p. 277-303, Crossref.

Weigand, E. (2015). Identity as a dialogic concept, în „Language and Dialogue”, vol. 5, no. 1, p. 7-22, Crossref.

Zafiu, R. (2009). Păcatele limbii: Rom, în „România literară”, nr. 10, [online]. 